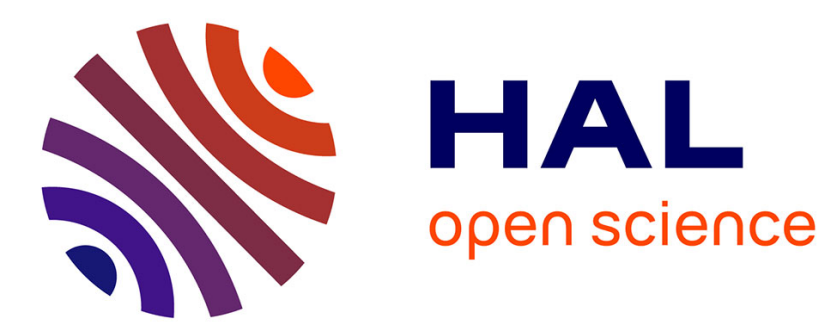

\title{
Low Temperature Deposition of TiN Ceramic Material by Metal Organic and/or Plasma Enhanced CVD
}

\author{
C. Spee, J. Driessen, A. Kuypers
}

\section{To cite this version:}

C. Spee, J. Driessen, A. Kuypers. Low Temperature Deposition of TiN Ceramic Material by Metal Organic and/or Plasma Enhanced CVD. Journal de Physique IV Proceedings, 1995, 05 (C5), pp.C5719-C5-734. 10.1051/jphyscol:1995587 . jpa-00253949

\section{HAL Id: jpa-00253949 https://hal.science/jpa-00253949}

Submitted on 1 Jan 1995

HAL is a multi-disciplinary open access archive for the deposit and dissemination of scientific research documents, whether they are published or not. The documents may come from teaching and research institutions in France or abroad, or from public or private research centers.
L'archive ouverte pluridisciplinaire HAL, est destinée au dépôt et à la diffusion de documents scientifiques de niveau recherche, publiés ou non, émanant des établissements d'enseignement et de recherche français ou étrangers, des laboratoires publics ou privés. 


\title{
Low Temperature Deposition of TiN Ceramic Material by Metal Organic and/or Plasma Enhanced CVD
}

\author{
C.I.M.A. Spee, J.P.A.M. Driessen and A.D. Kuypers \\ TNO Institute of Applied Physics, Department of Materials Chemistry and Coatings, P.O. Box 595, \\ 5600 AN Eindhoven, The Netherlands
}

\begin{abstract}
A review is presented describing the development of TiN-CVD from the classical, high temperature $\mathrm{TiCl}_{4} / \mathrm{N}_{2}$ process, towards low temperature MOCVD processes. This development is presented from a chemical point of view. In addition to low pressure (LPCVD) and atmospheric pressure (APCVD) thermal processing, also plasma enhanced (PECVD) techniques are described.

In the past few years production facilities for good quality TiN layers for wear resistant applications have come on the market. Production facilities for IC-technology applications of CVD-TiN are on the edge of breaking through. For both applications deposition temperatures have been reduced to $500-600^{\circ} \mathrm{C}$. Research developments, have shown even lower deposition temperatures possible for $\operatorname{TiN}$ and $\operatorname{Ti}(\mathrm{C}, \mathrm{N})$ layers.
\end{abstract}

\section{INTRODUCTION}

Chemical vapour deposition (CVD) of ceramic coatings has attracted attention for more than four decades. The amount of research and the scope of ceramic layers deposited by CVD is still increasing. A small list of areas where ceramic coatings are used and studied includes wear resistant layers (e.g. TiN, $\mathrm{TiC}, \mathrm{SiC}$, etc.), corrosion resistant layers $\left(\mathrm{Al}_{2} \mathrm{O}_{3}, \mathrm{Si}_{3} \mathrm{~N}_{4}, \mathrm{SiC}\right.$, etc.), electro-optic ceramics (e.g. PZT, $\mathrm{LiNbO}_{3}$ and electrochromic materials as $\mathrm{WO}_{3}, \mathrm{NiO}$, etc.), superconductors (e.g. $\mathrm{YBa}_{2} \mathrm{Cu}_{3} \mathrm{O}_{7-\mathrm{x}}$, etc.), dielectric's (e.g. $\mathrm{SrTiO}_{3}, \mathrm{BaTiO}_{3}$, etc.), and many more.

Drawback of CVD processes for the deposition of ceramic layers is generally the high process temperature $\left(600-1100^{\circ} \mathrm{C}\right)$. This limits the range of substrates that can be coated by CVD-techniques, and excludes substrates like glass, tool steels and products that have to be manufactured with low size tolerances). PVD techniques are usually applied to coat these substrates. However PVD techniques are "line of sight" processes, which make homogeneous deposition or deposition in small trenches, more difficult. This results amongst others in a lower load factor of products. CVD processes generally do not have this problem, and give conformal coverage, with higher growth rates and higher loading factors.

The two most promising routes that are being studied to lower the deposition temperature of CVD processes, are the application of glow discharges to dissociate the precursors (Plasma Enhanced CVD (PECVD)), and the application of metalorganic and organometallic precursors which dissociate at much lower temperatures (Metal Organic CVD (MOCVD)). A third route is to use photons for dissociation, 
like for example in photo- or laser-CVD of ceramic layers on heat sensitive substrates. Their application however is rather limited and does not yet play a role in large volume deposition.

In this review, we will restrict ourselves to the CVD deposition of TiN, as this is still the material most used as wear and corrosion resistant layer and because it is a material widely studied as barrier for ICtechnology applications. Also the Ti-chemistry involved, has a large resemblance with the chemistry necessary to deposit $\mathrm{Zr}$-, Hf-, $\mathrm{V}$ - and $\mathrm{Nb}$-nitrides and carbonitrides.

\section{THERMAL CVD}

\subsection{Inorganic Ti precursors}

More than 40 years ago research on the CVD of TiN has started. For the last two decades deposition of TiN on tool materials has been commercially available. Most of the commercial processes used today apply atmospheric pressure CVD (APCVD) in hot-wall reactors, using $\mathrm{TiCl}_{4}$ as Ti-precursor and $\mathrm{N}_{2}$ or $\mathrm{NH}_{3}$ as nitrogen source. The overall deposition reaction is shown in equation 1 . This reaction is usually performed in the temperature range of $900-1200^{\circ} \mathrm{C}$, with typical deposition rates of $0.03-0.2 \mu \mathrm{m} / \mathrm{min}$ and typical hardnesses of 2000-2500 HV. More details on this high temperature process can be found in a series of review articles $[33,59,121]$.

$$
\mathrm{TiCl}_{4}+1 / 2 \mathrm{~N}_{2}+2 \mathrm{H}_{2}-->\mathrm{TiN}+4 \mathrm{HCl}
$$

The relatively high deposition temperature in this process however puts a large restriction to the range of substrates which can be coated with TiN. A large range of heat sensitive materials like glass, aluminium, polymers, tool steels, but also products made from heat resistent materials, which have to be coated at a production stage where form changes or layer interactions cannot be permitted, cannot be coated with this classical CVD process. Presently the most important example, where low temperature deposition of TiN is definitely required, is the processing for the production of integrated circuits (IC), where a maximum deposition temperature of $450^{\circ} \mathrm{C}$ is allowed for the deposition of TiN-barrier layers.

With the addition of $\mathrm{NH}_{3}$, TiN can be deposited at lower temperatures. The overall reaction, is shown in equation 2. The actual chemistry is however very complicated and in no way represented by this simple equation.

$$
6 \mathrm{TiCl}_{4}+8 \mathrm{NH}_{3}-->6 \mathrm{TiN}+\mathrm{N}_{2}+24 \mathrm{HCL}
$$

Thermodynamically this reaction is favourable above $\pm 300^{\circ} \mathrm{C}$, but only reasonable film growth is obtained above $400-450^{\circ} \mathrm{C}$. Many references describe the use of LPCVD [9, 24, 27, 28, 34, 38, 53, 58, 63, $73,80,81,84,114,134]$, with IC-technology as the most important application. For the deposition of TiN for IC-applications a low pressure is preferred to obtain a good step coverage in trenches. Only a limited amount of papers describe this process using APCVD $[6,55,64]$. The $\mathrm{TiCl} 4 / \mathrm{NH}_{3}$ process suffers from an unfavourable side reaction, the formation of $\mathrm{TiCl}_{4} . \mathrm{xNH}_{3}$ complexes (equation 3). These complexes already form at room temperature and are stable up to about $200^{\circ} \mathrm{C}$. At temperatures between $200-400^{\circ} \mathrm{C}$ it decomposes to $\mathrm{TiN}_{\mathrm{x}} \mathrm{Cl}_{\mathrm{y}}$ giving finally $\mathrm{TiN}$ at temperatures above $400^{\circ} \mathrm{C}$.

$$
\mathrm{TiCl}_{4}+2 \mathrm{NH}_{3}--->\mathrm{TiCl}_{4} \cdot 2 \mathrm{NH}_{3} \text { (yellow solid) }
$$


At atmospheric pressure this complex formation can give rise to a large quantity of unwanted powder. Reduction of this formation can be obtained by mixing the $\mathrm{TiCl}_{4}$ and $\mathrm{NH}_{3}$ not before entering the reactor, and making sure that the precursor inlet tubes are heated to temperatures preferable above $250^{\circ} \mathrm{C}$. At temperatures between $250-300^{\circ} \mathrm{C}, \mathrm{TiCl}_{4} / \mathrm{NH}_{3}$ mixtures do not immediately form these solid by-products [10].

One of the most important issues in the low temperature deposition using $\mathrm{TiCl}_{4}$ is the amount of $\mathrm{Cl}$ in the TiN layer. Almost all references describe $\mathrm{Cl}$ contamination in the deposited TiN layers. Figure 1 shows a representative example of the variation of chlorine content with the deposition temperature, measured by Buiting et al. [38].

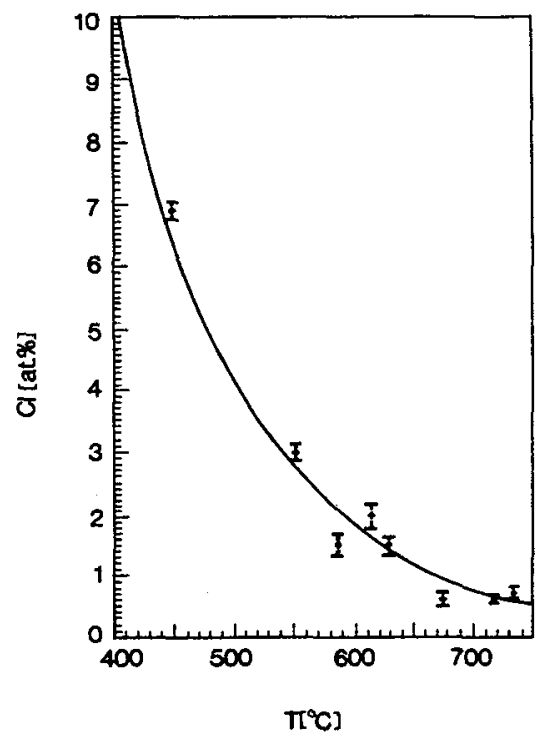

Fig. 1 Variation of the chlorine content with the deposition temperature for the LPCVD $\mathrm{TiCl}_{4} / \mathrm{NH}_{3}$ process [38]

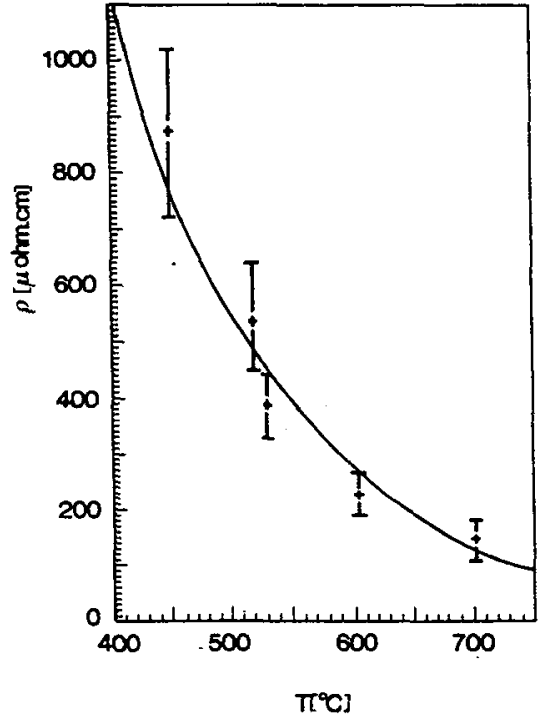

Fig. 2 Resistivity of LPCVD TiN vs, deposition temperature for layers deposited using the $\mathrm{TiCl}_{4} / \mathrm{NH}_{3}$ process [38].

For many applications TiN with a chlorine contamination of more than about 1-2 at $\%$, is not wanted. It might cause etching of materials like steel or aluminum substrates and aluminium conducting layers (see also figure 5 in paragraph 3.1. During the deposition process the chlorine can attack steel substrates.

For IC-technology application the resistivity of the deposited TiN is very important, as it is a/o. used as contact material between silicon and aluminium contact paths. The resistivity of TiN should be below about $200 \mu \mathrm{Ohm} . \mathrm{cm}$. Buiting et al. [38] determined the resistivity of TiN layers vs. deposition temperature and hence the amount of $\mathrm{Cl}$ content (see figure 2). A minimal substrate temperature of $600^{\circ} \mathrm{C}$ is necessary, to obtain usable TiN layers. This high temperature limits the use of this process for IC technology applications. It also is not yet clear if the remaining 1-2 at\% of $\mathrm{Cl}$ causes problems in the life-time of an IC.

A few references have appeared where instead of $\mathrm{N}_{2}$ or $\mathrm{NH}_{3}$ alternative nitrogen precursors are used to decrease the deposition temperature $[1,74,84,90,118]$. Using ${ }^{\mathrm{t}} \mathrm{BuNH}_{2}$ (tertiair butyl amine) instead of $\mathrm{NH}_{3}$ gave similar layer qualities, but at a reduced deposition temperature of about $50-100^{\circ} \mathrm{C}[74,84,90]$. The use of $\left(\mathrm{CH}_{3}\right) \mathrm{HNNH}_{2}$ (methyl hydrazine) made it posssible to reduce the temperature with another 
$100^{\circ} \mathrm{C}$, and to increase the deposition rate with about one order of magnitude $[84,118,135]$. Methy] hydrazine is however not a very pleasant compound to be used, because of the fact that it easily explodes. Also due to the fact that now a carbon containing precursor is present in the process, some carbon impurities are found. Wakefield et al [1] describe the formation of $\mathrm{Ti}(\mathrm{C}, \mathrm{N})$ by the use of a series of amines. They find low amounts of $\mathrm{TiC}(18 \mathrm{~mol} \%)$ using $\left(\mathrm{CH}_{3}\right) \mathrm{HNNH}\left(\mathrm{CH}_{3}\right)$ (dimethyl hydrazine) and increasing amounts going from $\left(\mathrm{CH}_{3}\right) \mathrm{NH}_{2}$ monomethylamine, $\left(\mathrm{CH}_{3}\right)_{2} \mathrm{NH}$ (dimethylamine), $\left(\mathrm{CH}_{3}\right)_{3} \mathrm{~N}$ (trimethylamine) to $\left(\mathrm{CH}_{3} \mathrm{CH}_{2}\right)_{3} \mathrm{~N}$ (triethylamine) which is almost completely $\mathrm{TiC}$ (almost $80 \%$ ).

Goldberg et al. [130] describe TiN deposition using TiI 4 as titanium precursor. Equation 3 shows the overall reaction. They find good TiN layers, with resistivities between 44-288 $\mu \mathrm{Ohm}$.cm using deposition

$$
2 \mathrm{Til}_{4}+\mathrm{H}_{2}+2 \mathrm{NH}_{3}--->2 \mathrm{TiN}+8 \mathrm{HI}
$$

temperatures ranging from $375-450^{\circ} \mathrm{C}$. The I content in the TiN layers is less than 1.5 at $\%$ in this temperature range. This decrease in deposition temperature is ascribed to the lower dissociation energy of the primary bonds in Til4. The heat of formation for Til 4 is $-92 \mathrm{kcal} / \mathrm{mole}$, as compared to $-192 \mathrm{kcal} / \mathrm{mole}$ for $\mathrm{TiCl}_{4}$.

\subsection{Metal organic or organometallic Ti precursors}

Clearly the deposition temperatures needed to deposit good quality $\mathrm{TiN}$ with $\mathrm{TiCl}_{4}$, even though it has been reduced dramatically to temperatures down to $500^{\circ} \mathrm{C}$, is still too high for many applications. One of the reasons for this is the relatively high chemical stability of $\mathrm{TiCl}_{4}$. As we have seen this lowest temperature can be reduced with about $100^{\circ} \mathrm{C}$ using the less stable Til4. However, $400^{\circ} \mathrm{C}$ deposition temperature is even for some applications too high. One way of trying to overcome this problem is to search for titanium containing metalorganic or organometallic precursors, (generally described by MO-precursors), which are able to undergo a reaction with nitrogen or nitrogen containing species at lower temperatures, or which due to the fact that they have nitrogen containing ligands, can form TiN by decomposition itself, at lower temperatures than the processes described in paragraph 2.1. When MO-precursors are used the general term Metalorganic Chemical Vapour Deposition or MOCVD is used.

In MO-precursors, the organic ligands surrounding the, often central, titanium atom, may or may not contain nitrogen $[22,46,68,69]$. In the second case, a nitrogen supplier has to be added to the CVD system. In the first case, when no nitrogen supplier is added to the gas flow, titanium nitride may also result from decomposition of the precursor.

Several types of precursors have been tested on their capability of forming clean TiN, but after meeting requirements like good thermal stability, high volality and low costs, not many precursors remain interesting. Table 1 shows an overview of the precursors described in literature. Among these MO precursors, much attention is paid to the deposition behaviour of $\mathrm{Ti}\left(\mathrm{NMe}_{2}\right)_{4}$ and $\mathrm{Ti}\left(\mathrm{NE}_{2}\right)_{4}$, in which the central $\mathrm{Ti}$ atom is surrounded by four di(m)ethylamino ligands. Using these species, temperatures as low as $200^{\circ} \mathrm{C}$ have been realised to deposit titanium nitride $[48,70,82,85,86,122]$. Other interesting species are $\mathrm{CpTiC}_{7} \mathrm{H}_{7}$ and ${ }^{\mathrm{t}} \mathrm{Bu}\left(\mathrm{NMe}_{2}\right)_{3}$ but have not been investigated so widely.

\# Metal organic compounds are defined as chemicals containing metal nitrogen or metal oxygen bonds (e.g. $\left.\mathrm{Ti}\left(\mathrm{NMe}_{2}\right)_{4}\right)$, where organometallic compounds have metal carbon bonds (e.g. $\mathrm{CpTiC}_{7} \mathrm{H}_{7}$ ) 


\begin{tabular}{|c|c|c|c|}
\hline Precursor & Temperature range & Process & References \\
\hline $\mathrm{Ti}\left(\mathrm{NMe}_{2}\right)_{4}$ & $\begin{array}{l}100-500^{\circ} \mathrm{C} \\
55-580^{\circ} \mathrm{C} \\
100-600^{\circ} \mathrm{C}\end{array}$ & $\begin{array}{l}\text { APCVD } \\
\text { LPCVD } \\
\text { PECVD }\end{array}$ & $\begin{array}{l}4,29,39,48,95,133 \\
31,43,60,65,70,71,72,78,84,85,91,93, \\
103,104,105,120,122,126,129,132 \\
51,52,54,82,92,95,96,97,107,108,113, \\
124,125,131\end{array}$ \\
\hline $\mathrm{Ti}\left(\mathrm{NEt}_{2}\right)_{4}$ & $\begin{array}{l}350-600^{\circ} \mathrm{C} \\
160-500^{\circ} \mathrm{C} \\
250-550^{\circ} \mathrm{C} \\
\end{array}$ & $\begin{array}{l}\text { APCVD } \\
\text { LPCVD } \\
\text { PECVD } \\
\end{array}$ & $\begin{array}{l}28,79,95 \\
54,77,102,119,120,122,128,134 \\
51,52,76,82,86,92,95,96,108 \\
\end{array}$ \\
\hline $\operatorname{Ti}(\mathrm{N}(\mathrm{Me}) \mathrm{Et})_{4}$ & $\begin{array}{l}350-500^{\circ} \mathrm{C} \\
350^{\circ} \mathrm{C}\end{array}$ & $\begin{array}{l}\text { APCVD } \\
\text { PECVD }\end{array}$ & $\begin{array}{l}29 \\
76,108 \\
\end{array}$ \\
\hline $\mathrm{t}_{\mathrm{BuTi}}\left(\mathrm{NMe}_{2}\right)_{3}$ & $\begin{array}{l}300-400^{\circ} \mathrm{C} \\
300-600^{\circ} \mathrm{C} \\
\end{array}$ & $\begin{array}{l}\text { APCVD } \\
\text { LPCVD }\end{array}$ & $\begin{array}{l}29 \\
91 \\
\end{array}$ \\
\hline $\mathrm{CpTiC}_{7} \mathrm{H}_{7}$ & $\begin{array}{l}500-625^{\circ} \mathrm{C} \\
300-600^{\circ} \mathrm{C} \\
\end{array}$ & $\begin{array}{l}\text { LPCVD } \\
\text { PECVD }\end{array}$ & $\begin{array}{l}91 \\
76,100,101,108 \\
\end{array}$ \\
\hline $\mathrm{Ti}\left(\mathrm{NC}_{4} \mathrm{H}_{8}\right)_{4}$ & $\begin{array}{l}400^{\circ} \mathrm{C} \\
350^{\circ} \mathrm{C}\end{array}$ & $\begin{array}{l}\text { APCVD } \\
\text { PECVD }\end{array}$ & $\begin{array}{l}58 \\
76 \\
\end{array}$ \\
\hline $\mathrm{Ti}\left(\mathrm{NC}_{5} \mathrm{H}_{10}\right)_{4}$ & $400-650^{\circ} \mathrm{C}$ & APCVD & 58 \\
\hline$\left[\mathrm{Ti}\left(\mu-\mathrm{N}-\mathrm{t}_{\mathrm{Bu}}\right)\left(\mathrm{NMe}_{2}\right)_{2}\right]_{2}$ & $\begin{array}{l}400-450^{\circ} \mathrm{C} \\
300-500^{\circ} \mathrm{C} \\
\end{array}$ & $\begin{array}{l}\text { APCVD } \\
\text { LPCVD } \\
\end{array}$ & $\begin{array}{l}29 \\
91 \\
\end{array}$ \\
\hline $\mathrm{Ti}\left({ }^{\mathrm{t}} \mathrm{BuDAD}\right) 2$ & $\begin{array}{l}400-500^{\circ} \mathrm{C} \\
? \\
\end{array}$ & $\begin{array}{l}\text { LPCVD } \\
\text { PECVD } \\
\end{array}$ & $\begin{array}{l}91 \\
41 \\
\end{array}$ \\
\hline FTi $\left[\mathrm{N}\left(\mathrm{SiMe}_{3}\right)_{2}\right]_{3}$ & $500-740$ & LPCVD & 115 \\
\hline$\left[\mathrm{TiCl}_{2}\left(\mathrm{NH}^{\mathrm{t}} \mathrm{Bu}\right)_{2}\left(\mathrm{NH}_{2}{ }^{\mathrm{t}} \mathrm{Bu}\right)_{2}\right]_{2}$ & $500^{\circ} \mathrm{C}$ & LPCVD & 75,111 \\
\hline $\mathrm{TiCl}_{4}\left(\mathrm{NH}_{3}\right)_{2}$ & $475-600^{\circ} \mathrm{C}$ & LPCVD & 127 \\
\hline $\mathrm{TiCl}_{4}(\mathrm{TPPO})_{2}$ & $475-600^{\circ} \mathrm{C}$ & LPCVD & 127 \\
\hline $\mathrm{CpTiCl}_{2} \mathrm{~N}\left(\mathrm{SiMe}_{3}\right)_{2}$ & $400-600^{\circ} \mathrm{C}$ & LPCVD & 67,68 \\
\hline $\operatorname{ClTi}(\mathrm{Me})\left(\mathrm{Cp}^{*}\right)_{2}$ & $250-450^{\circ} \mathrm{C}$ & PECVD & 52,108 \\
\hline
\end{tabular}

Table 1 Overview of Ti-MO-precursors for TiN, including the CVD techniques and deposition temperature ranges used with these precursors.

Depending on the application, TiN layers must be dense, without pinholes or contamination and should have good uniformity over the substrate. Because until now, most attention is paid to the application of TiN in microelectronic devices, resistivity is also an important property. The quality of these properties is very much dependent on the type of production process and the parameters used.

\subsection{1 $\mathrm{Ti}\left(\mathrm{NR}_{2}\right)_{4}$}

By far the most studied metalorganic Ti-precursors used for the deposition of TiN are the methyl and ethyl analogues of tetrakis(dialkylamido)titanium (see references in table 1).

To be able to deposit high quality layers, it is important to determine what the actual process steps are and what the reaction mechanism is. As with other CVD processes, these mechanisms are determined by process parameters like temperature, pressure, substrate material, reactor geometry etc. The mechanisms that govern the TiN deposition process, using $\mathrm{Ti}\left(\mathrm{NMe}_{2}\right) 4$ and $\mathrm{Ti}\left(\mathrm{NEt}_{2}\right) 4$, are not clear yet. In most cases, 
these precursors are used in combination with ammonia, although nitrogen is already present $[48,60,70$, $82,85,86,122]$.

Reaction mechanisms - Thermal decomposition of pure $\mathrm{Ti}\left(\mathrm{NR}_{2}\right) 4$ without $\mathrm{NH}_{3}$, seems to result in TiN layers with large carbon contamination's. Of this decomposition reaction, $\beta$-hydrogen elimination seems to be an important step $[29,60]$. Hydrogen in ligands will activate the bond between carbon and titanium of neighbour ligands and a metallacycle will result via loss of dimethylamine (see equation 4, in case of

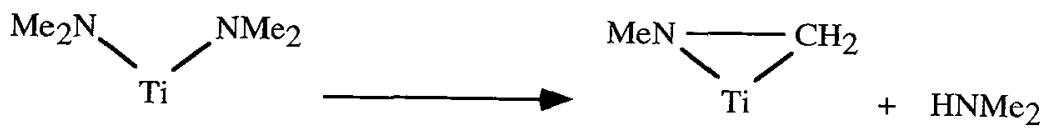

$\left.\mathrm{Ti}\left(\mathrm{NMe}_{2}\right) 4\right)$. This mechanism accounts for the TiC found in the deposited TiN layers.

From the combination of $\mathrm{NH}_{3}$ and $\mathrm{Ti}\left(\mathrm{NR}_{2}\right)_{4}$, with hydrogen and/or nitrogen as carriergas, one of the most important reaction steps is the transamination reaction. This reaction consists of the exchange of amines. Equation 5 shows the general reaction for $\mathrm{Ti}\left(\mathrm{NMe}_{2}\right) 4$ ), with $\mathrm{n}=1$ to 4 Use of deuterated ammonia

$$
\mathrm{Ti}\left(\mathrm{NMe}_{2}\right)_{4}+\mathrm{nHNR}_{2}--->\mathrm{Ti}\left(\mathrm{NMe}_{2}\right) 4-\mathrm{n}\left(\mathrm{NR}_{2}\right) \mathrm{n}+\mathrm{nHNMe} 2
$$

$\mathrm{ND}_{3}$ and ${ }^{15} \mathrm{NH}_{3}$ confirmed this exchange mechanism. [60, 82, 85]. By further reactions (most importantly $\beta$-elimination; eq. 4 ), the resulting compound is converted to $\mathrm{TiN}$, which is often oligomeric. Dubois et al. [104] find almost no transamination reaction occurring under deposition conditions yielding TiN with high levels of carbon contamination, indicating that an intramolecular process (e.g. eq. 4) is dominating the chemistry. They find that as the $\mathrm{NH}_{3}: \mathrm{Ti}_{\left(\mathrm{NMe}_{2}\right)} 4$ ratio is increasing, the level of carbon contamination decreases until for a film containing low percentages of carbon $(\sim 5 \%)$, all the nitrogen in the film originates from $\mathrm{NH}_{3}$, suggesting a intermolecular process (as in eq. 5). We have found [91] porous black coloured $\mathrm{TiN}$ layers with low $\mathrm{C}$ impurities using high $\mathrm{Ti}\left(\mathrm{NMe}_{2}\right) 4 / \mathrm{NH}_{3}$ ratios, from which after heating up to $700^{\circ} \mathrm{C}$, a considerable amount of $\mathrm{NH}_{3}$ was liberated, and only low amounts of carbon containing species. These results seem to be in agreement with the results from Dubois et al [104]. However, the complete chemistry is not clear yet. One of the difficulties of the above mechanism is the poorly understood reduction of $\mathrm{Ti}(\mathrm{IV})$ to $\mathrm{Ti}(\mathrm{III})$ [104]. $\beta$-elimination reactions result in the formation of $\mathrm{NTi}^{\mathrm{IV}} \mathrm{NR}_{2}$. It is not clear how this is converted into $\mathrm{Ti} \mathrm{II}_{\mathrm{N}}$. From gas phase studies it is indicated that gas phase reactions may be as important as the surface chemistry. Specifically, the surface reactions responsible for the growth of TiN films involve intermediates according to eq. 5 that are formed in the gas phase.

Contamination's - The problem that arises, using $\mathrm{Ti}\left(\mathrm{NR}_{2}\right) 4$ type precursors with or without ammonia, is incorporation of contaminants like carbon and hydrogen in surface layers. These contaminants can severely effect the desired properties of the layer. Carbon can be built in the layer in different process steps. Different ways of incorporation, result in different types of bonds between carbon and the bulk material. Carbon may be bonded directly to $\mathrm{Ti}$ to form $\mathrm{TiC}$. This material has some TiN-like properties, it is even harder than TiN and has a resistivity in the same order as TiN. Carbon however, can also be incorporated as graphite precipitates, or as not completely reduced organic impurities. These carbon contamination's are highly unwanted, because it almost always reduces the quality of the TiN layer.

Similar amounts of hydrogen can be incorporated using large $\mathrm{NH}_{3} / \mathrm{TiCl}_{4}$ ratios. It causes the TiN layers to be non-dense [91] with bad wear resistant properties. 
It seems that thermal decomposition of $\mathrm{Ti}\left(\mathrm{NR}_{2}\right) 4$ without ammonia results in rather high levels of carbon and hydrogen in the layers. Metallacycle's are quite stable and once adsorbed TiC or organic by-products may be formed $[60,83]$. Ti(C,N) layers have been produced by thermal decomposition containing more than 40 at $\%$ carbon $[29,82,83]$. Rapid thermal MOCVD processes gave somewhat better results ${ }^{\text {t }} \mathrm{Bu}$ the produced layers still contained $26-35$ at\% $\mathrm{C}$ [43]. Changing process parameters as temperature and pressure do not seem to have much influence. High carbon values are always reported $[29,43,82,83]$. Increasing temperature results generally in a small increase in carbon content $[43,82]$ The opposite influence is noticed from pressure increment [43].

Also oxygen impurities are usually found in the deposited TiN layers, even though there is no oxygen present in the precursors. Ti is very reactive with oxygen. Ti-precursors to a small extend and several intermediates to a large extent will react with every oxygen atom present in the process. Ti-chips are often used as catalyst to purify gases from oxygen. $\mathrm{TiO}_{2}$ increases the resistivity of $\mathrm{TiN}$ layers dramatically, which makes them less usefull for microelectronic applications $[29,43,82,93]$. Therefore very clean, oxygen and especially water free reactors have to be used. This is often accomplished by using LPCVD reactors with very low background pressures. Unfortunately also the precursors often contain metal-organic impurities with oxygen in their ligands. It is also observed that some of the TiN layers deposited are oxidised after exposure to air [91]. Especially porous TiN layers with organic and/or hydrogen impurities can oxidise to a considerable extend. Oxidation of the TiN interface, can however also be advantageous. It can strengthen the TiN diffusion barrier [122].

Resistivities, varying from $425-5000 \mu \mathrm{Ohm} . \mathrm{cm}$ have been found $[29,43,82,91,93]$. Temperature does not seem to have much influence in the incorporation of oxygen. Increasing process pressures do cause a large increase in oxygen content [43].

In the literature most attention is paid to TiN deposition with the $\mathrm{T}\left(\mathrm{NR}_{2}\right) / \mathrm{NH}_{3}$ process, with $\mathrm{R}=\mathrm{Me}$, Et. The addition of $\mathrm{NH}_{3}$ gives better results with respect to impurity levels [see references in table 1]. The layers can in general be characterised as smooth with sufficiently high conformality and low resistivities to be applicable for IC-technology applications [70, 122]. Raaijmakers et al. [70], obtain resistivities of about $180 \mu \mathrm{Ohm} . \mathrm{cm}$ at $425^{\circ} \mathrm{C}$ with low impurity levels $(<3 \% \mathrm{C},<0.5 \%$ O). In figure 3 , the impurities of the layers obtained by Raaijmakers et al [70] are compared with layers obtained by the $\mathrm{TiCl}_{4} / \mathrm{NH}_{3}$ process.

At low pressures, opposite behaviour is observed as compared to the atmospheric pressure process. At low pressure, increasing temperature and decreasing pressure generally results in rougher surfaces and a lower conformality but on the other hand in lower carbon contents $[70,122]$. On the contrary at atmospheric pressure an increase in carbon content is reported upon increasing deposition temperature [39]. However the amount of carbon incorporated at atmospheric pressure is considerably lower, even at high temperatures

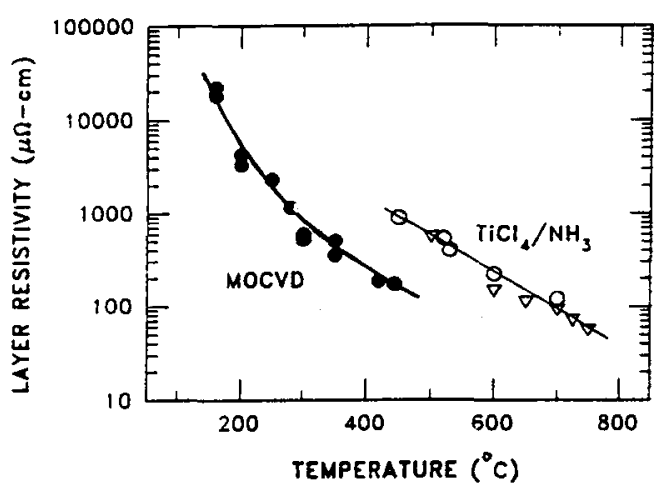

Fig. 3 Resistivity of LPCVD TiN vs. deposition temperature. Bullets: Ti(NEt 2$)_{4} / \mathrm{NH}_{3}$ che mistry 70]; Open circles [38], Diamonds [24]: $\mathrm{TiCl}_{4} / \mathrm{NH}_{3}$ process. 
than with LPCVD. Mechanisms describing the incorporation of carbon are only speculative.

The use of $\mathrm{Ti}\left(\mathrm{NEt}_{2}\right) 4$ instead of $\mathrm{Ti}\left(\mathrm{NMe}_{2}\right)_{4}$ results in layers with lower resistivities, lower oxygen content, somewhat lower carbon content and higher conformality [120]. The methylamido ligands seem to be more reactive and more easily to break up. The ethylamido ligands are more stable and the central $\mathrm{Ti}$ atom is better protected from uncontrolled gasphase reactions. The deposition rates however are also lower.

\subsection{2 ${ }^{t_{B u T i}\left(\mathrm{NMe}_{2}\right) 3}$}

As described previously, the problem to reduce the $\mathrm{Ti} I \mathrm{~V}$ compound to $\mathrm{Ti} \mathrm{III}$, is believed to be one of the causes of the incorporation of $\mathrm{C}$. Therefore, the molecule ${ }^{\mathrm{t}} \mathrm{BuTi}\left(\mathrm{NMe}_{2}\right)_{3}[29,30,91]$ has gained some interest. This molecule contains the loosely bonded $t_{\mathrm{Bu}}$ ligand. It is believed that this molecule dissociates according to equation 6 , with the formation of a ${ }^{\mathrm{t}} \mathrm{Bu}$ radical and a $\mathrm{Ti}$ III compound.

$$
\left.\left.\mathrm{t}_{\mathrm{BuTi}} \mathrm{IV}_{(\mathrm{NR} 2) 3->\mathrm{Ti}} \mathrm{III}_{(\mathrm{NR}}\right)_{3}\right)+\mathrm{t}_{\mathrm{Bu}}
$$

Experiments with this precursor have been executed at atmospheric [29] and at low pressures [91]. The results show the same level of carbon impurities as compared with $\mathrm{Ti}\left(\mathrm{NMe}_{2}\right) 4$ as precursor, even though the compound contains more carbon. It is suggested that there is still a common intermediate involved in the further decomposition process with ${ }^{{ }^{B}} \mathrm{BuTi}\left(\mathrm{NR}_{2}\right)_{3}$ just as with $\operatorname{Ti}\left(\mathrm{NR}_{2}\right)_{4}$ [29]. However, although the amount of carbon impurities did not decrease, on the other hand the amount of oxygen, (and associated with it the resistivity) did decrease using ${ }^{\mathrm{t}} \mathrm{BuTi}\left(\mathrm{NMe}_{2}\right)_{3} / \mathrm{NH}_{3}$ [91]. We believe that the reactive ${ }^{\mathrm{t}} \mathrm{Bu} \cdot$ radicals are acting as oxygen scavengers in the CVD system. Resistivities below $300 \mu \mathrm{Ohm} . \mathrm{cm}$ are obtained [66].

\subsubsection{Alternatives}

Several other precursors have been studied for the thermal LPCVD deposition of TiN (see table 1). As yet, none of them has been successfully used to deposit good quality layers at temperatures below $450^{\circ} \mathrm{C}$. Partly, this originates from the low amount of thermal experiments described till now. A large part of the alternative precursors still contain one of more chlorine ligands. As expected none of them produced TiN layers without chlorine impurities. Nonetheless they are studied with the hope that the impurities can be decreased considerably, without real big success up till now. The $\mathrm{CpTiC}_{7} \mathrm{H}_{7} / \mathrm{NH}_{3}$ system has shown to be an interesting precursor for the deposition of TiN [91], with resistivities at $500^{\circ} \mathrm{C}$, comparable to the previously described systems. Unfortunately, the kinetics of the $\mathrm{CpTiC}_{7} \mathrm{H}_{7} / \mathrm{NH}_{3}$ system has shown it to be kinetically limited at temperatures at least below $600^{\circ} \mathrm{C}$. At $500^{\circ} \mathrm{C}$ the thermal growth rate is unfortunately already too low for practical applications.

\subsubsection{Conclusion $\mathrm{s}$}

Of these thermal processes, results are promising but, as can be concluded, the desired low deposition temperature in combination with a low degree of contamination is still not reached. Especially when also high conformality in $0.25 \mu \mathrm{m}$ microelectronic devices is desired. To be able to decrease the deposition temperature, other ways of exciting the reacting species must be searched for, like (remote) plasma excitation.

The presence of organic and graphitic carbon, together with the low density of the layers tends to make them unsuitable for use as hard and wear resistant coatings. 


\section{PLASMA ACTIVATED CVD}

One way of breaking chemical bonds is by thermal activation. As we have seen in the previous section minimum temperatures necessary to establish chemical reaction or decomposition can be reduced considerably by changing the chemistry (usage of $\mathrm{NH}_{3}$ ) or by using precursors with lower bond strengths (TiL4, MO-precursors). However, lowest temperatures of $200-300^{\circ} \mathrm{C}$ are still necessary. And although TiN is formed at low temperatures, the growth rates are usually very low.

An alternative way of exciting reactants, is using plasma activation. In CVD processes a distinction must be made between direct and remote plasma activation. A direct plasma, is a plasma in direct contact with the substrate surface, such that the precursor molecules pass through the discharge itself. Substrate material can be heated at moderate temperatures just sufficient to ensure surface mobility and reactions, while in the gasphase excited particles and radicals are generated [3]. Plasma electrons are accelerated by an applied electric field and acquire sufficient energy to cause dissociation and ionisation of molecules by collisions. This may result in total decomposition of reactants in the gas phase $[3,4,57]$. Ions formed in the plasma are accelerated by the high electric field strength over the boundary layer between plasma and substrate. Using bias voltages, this electric field strength can be manipulated, thereby changing the impact energy of the ions on the substrate. At low energies these impacting ions can cause enhanced desorption of reaction products, where at high energies they can be implanted. Direct plasma's usually result in the incorporation of carbon in the layers $[51,54,96]$. Therefore, the resulting process is not suitable for pure TiN deposition (e.g. as wanted in microelectronic devices). Direct plasma's are however very useful for depositing $\mathrm{Ti}(\mathrm{C}, \mathrm{N})$ hard coatings. Especially the bombardments with accelerated ions and electrons $[4,57]$ can be used for etching and stress modification, resulting in the deposition of very dense and compressed $\mathrm{Ti}(\mathrm{C}, \mathrm{N})$. Impacting low energy ions can be used to enhance the desorption of carbonic complexes from the surface.

n remote-plasma CVD, the plasma is generated at a certain distance, from the substrate surface. Thus, fast plasma electrons can still produce excited radicals by collisions, while the produced ions escaping the plasma are neutralised before reaching the substrate. Thereby bombardment of the substrate, by energetic charged particles is avoided. Although sometimes the precursor itself is led through the remote plasma volume, it is common practice to introduce the precursor between plasma and substrate. The plasma is used as a source of excited coprecursor molecules, and radicals (e.g. Ar, He, $\mathrm{N}_{2} / \mathrm{N}$ ). By regulating the plasma power and thereby the internal energy of the coprecursor molecules and radicals, it might be possible to break the bonds within the precursor molecules selectively. In this way, also carbon free TiN for microelectronic devices, could be de posited at low temperatures.

As stated, direct plasma's can be used for the deposition of hard, wear resistant coatings. Most references describe the use of direct current plasma's (DC) $[45,51,54,92,96]$. Both continuous and pulsed DC plasma are used. A few references describe the use of radio frequency plasma's ( $R F, 13.56 \mathrm{MHz})[14]$.

\section{1 $\mathrm{TiCl}_{4}$}

Apart from a limited amount of references which describe the use of PECVD using $\mathrm{TiCl}_{4}$ as Ti-precursor for IC-technology applications [8, 26, 37, 109], a large series of articles have been published on the deposition of TiN as hard coating for wear resistant applications, by this technique $[14,23,37,40,42,45,47$, $49,50,88,89,106,112]$

Akahori et al. [37, 109] use ECR (Electron Cyclotron Resonance) PECVD, with a remote $2.45 \mathrm{GHz}$ microwave plasma to deposit TiN for IC-technology applications. Lower chlorine concentrations than with 
LPCVD-TiN were found. Also a low resistivity of $40 \mu \mathrm{Ohm} . \mathrm{cm}$ is found, using a deposition temperature of $540^{\circ} \mathrm{C}$. Unfortunately, the lowest deposition temperature necessary to deposit good quality TiN layers, is about $450^{\circ} \mathrm{C}$. Films deposited by ECR plasma CVD have low stress values, due to a counterbalance between compressive stress induced by ECR and tensile stress caused by thermal expansion.

PECVD TiN layers deposited for wear resistant applications are usually deposited at temperatures between $400-700^{\circ} \mathrm{C}$, using

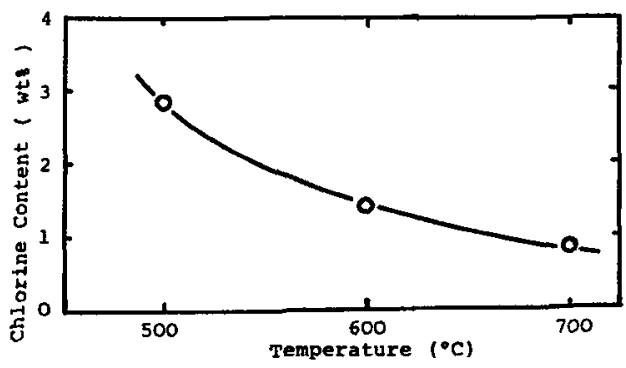

Fig. 4 Example of the variation of the chlorine content with the deposition temperature for the PECVD $\mathrm{TiCl}_{4} / \mathrm{N}_{2}$ process [7] $\mathrm{N}_{2}$ as nitrogen source. Also with PECVD, chlorine impurities are always found in increasing concentrations as the deposition temperature is decreasing (see figure 4). At deposition temperatures above about $500^{\circ} \mathrm{C}$, TiN layers with good corrosion resistance [112], good adhesion strength [49] and wear resistance [7] are found. Several references describe the relationship between hardness c.q. wear resistance vs. chlorine content in the TiN layer (see figure 5). In general, the layers consisted of columnar grains with good adherence $[14,45]$. The composition of these grains can be varied by changing the amount of nitrogen in the gas flow. The best hardness values generally found are between $2000-2400 \mathrm{HV}$ [37, 45, see also figure 5].

Freller et al. [40] compare PECVD TiN coatings deposited by different excitation methods for the glow discharge (DC discharge, RF discharge with DC bias and a pulsed DC discharge). After comparing advantages and disadvantages they conclude that the pulsed PECVD process is the most favourable. This is due to the simple process control, to a fairly good possibility of up scaling (DC techniques) and, most important, to the fact that it gives the best coating uniformity on three-dimensional parts.

A few references also describe PECVD of TiN using $\mathrm{TiCl}_{4} / \mathrm{NH}_{3}[8,9]$. Hilton et al. [9], find very low chlorine contents with $\mathrm{RF}$ discharge PECVD using $\mathrm{NH}_{3}$ instead of $\mathrm{N}_{2}$. Chlorine concentrations are al ready below 5 at\% at a temperature as low as $300^{\circ} \mathrm{C}$. Contradictory to these results, Gleason et al. [8] find results with the same process which are inferior to the $\mathrm{TiCl} 4 \mathrm{~N}_{2}$ PECVD system. We have not found any recent articles on the PECVD of TiN using $\mathrm{TiCl}_{4} / \mathrm{NH}_{3}$
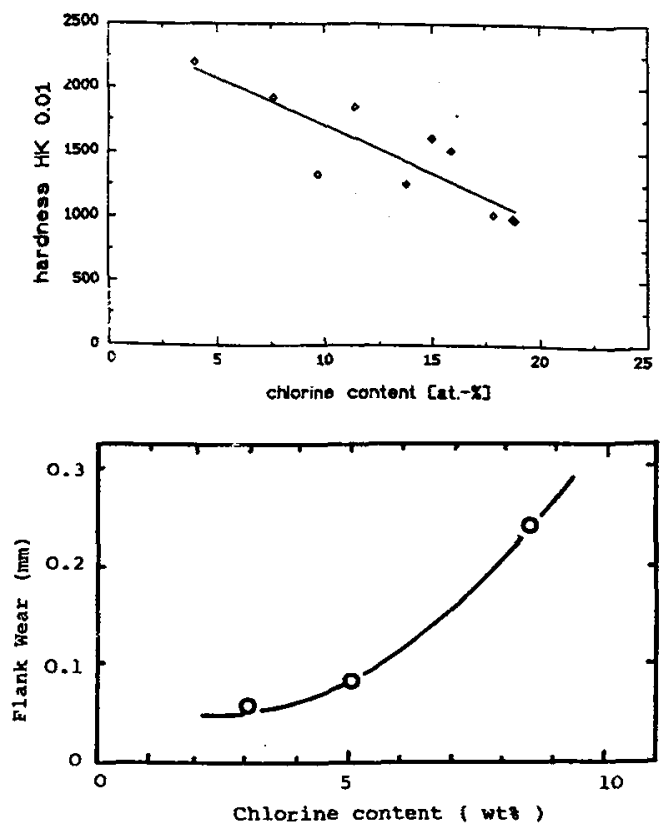

Fig. 5 Layer hardness (a) [37] and wear resistance (b) [7] as a function of chlorine content in TiN layers deposited by PECVD using the $\mathrm{TiCl} 4 / \mathrm{N}_{2}$ process. 


\subsection{MO-precursors}

As we have seen in the previous paragraph, good wear resistant layers have been obtained at much lower temperatures than for the classical thermal CVD process using $\mathrm{TiCl}_{4} / \mathrm{N}_{2}$, by enhancement of the growth using glow discharges. However, the deposited layers always contain chlorine contamination, when low deposition temperatures are used. Only at deposition temperatures above $500^{\circ} \mathrm{C}$, good layers are obtained (even though a small percentage of chlorine is still present). This is the reason why a considerable amount of research is being undertaken, to use MO-precursors in combination with plasma enhanced CVD. Table 1 summarises the MO-precursors being studied in combination with PECVD.

\section{Direct plasmas}

In the deposition of hard coatings for wear resistant applications only direct plasmas are being applied. As with LPCVD, two MO-precursors are mostly used, e.g. $\mathrm{Ti}\left(\mathrm{NMe}_{2}\right) 4$ and $\mathrm{Ti}\left(\mathrm{NEt}_{2}\right) 4$. Also the range of deposition temperatures is comparable, and is in most references in the range of $200-600^{\circ} \mathrm{C}$. At temperatures exceeding $550^{\circ} \mathrm{C}$, almost no deposition is reported. Beyond this temperature, most of the precursor is converted into powder by homogeneous reactions in the gas-phase $[54,96]$. Below this temperature, good adherent and dense layers are being produced. The morphology of the $\operatorname{Ti}(\mathrm{C}, \mathrm{N})$ layers shows columnar grains, which seem to decrease in size with increasing temperature [51, 92]. Adhesion of these layers seems to be good (30-50 N) [51].

A sufficient hydrogen partial pressure in the reactor is desired to minimise the amount of free-carbon contamination $[54,95,96]$. Although the deposition mechanism is unknown, it seems that hydrogen is involved with the reduction of $\mathrm{Ti}(\mathrm{IV})$. Chemical analysis showed that $\mathrm{Ti}-\mathrm{N}$, Ti-C and $\mathrm{C}-\mathrm{C}$ bonds are present in the layers [92]. The amount of carbon and nitrogen impurities, is dependent on the character of the precursor. $\mathrm{Ti}\left(\mathrm{NMe}_{2}\right) 4$ shows a very reactive behaviour. At low temperatures, carbon contents of 40 at\% and nitrogen contents of 20 at\% are found [54, 96]. Higher deposition temperatures result in increasing amounts of carbon and decreasing amounts of nitrogen and titanium in the layers [54, 96]. PECVD, using Ti(NEt 2$) 4$, resulted in $\mathrm{Ti}(\mathrm{C}, \mathrm{N})$ layers with considerable lower carbon content and higher nitrogen content [54]. With $\mathrm{Ti}\left(\mathrm{NEt}_{2}\right) 4$, the level of carbon and nitrogen in the deposited layers is independent of temperature, up to about $550^{\circ} \mathrm{C}$, where homogeneous reactions in the gas phase takes over [54]. This phenomenon is contributed to the lower reactivity and growth rate of $\operatorname{Ti}\left(\mathrm{NEt}_{2}\right) 4$ as compared with $\mathrm{Ti}\left(\mathrm{NMe}_{2}\right) 4$. Due to the lower reactivity of the precursor, soft ion bombardment of the surface can desorb organic by-products during growth of the layer. Nitrogen, which is more strongly bonded to the surface, is incorporated at a higher rate than the less strongly bonded carbon. Ti(NMe 2$)_{4}$ seems to be more reactive and layers grow faster, while the intensity of ion bombardments remains equal. Therefore, not all carbon containing organic by-products are being removed from the surface and incorporated in the layer [54]. Hardnesses reached are in the range of $1200-2500 \mathrm{HV}[51,54,92,96]$, and are slightly higher when $\mathrm{Ti}\left(\mathrm{NEt}_{2}\right)_{4}$ is used instead of $\mathrm{Ti}\left(\mathrm{NMe}_{2}\right)_{4}$.

Oxygen impurities in the $\mathrm{Ti}(\mathrm{C}, \mathrm{N})$ layers are only detected in small amounts, probably due to traces of $\mathrm{O}_{2}$ and $\mathrm{H}_{2} \mathrm{O}$ in the source gases and precursors, or absorbed at the walls of the reactor or by oxidation of the deposited $\mathrm{Ti}(\mathrm{C}, \mathrm{N})$ layer after exposure to air $[54,92,96]$.

Hardly any other MO-precursors have been tested for the PECVD of Ti(C,N) in combination with direct plasmas. Berndt et al [76] use $\mathrm{Ti}(\mathrm{NMeEt})_{4}$ and $\mathrm{Ti}\left(\mathrm{NC}_{4} \mathrm{H}_{8}\right)_{4}$ as alternative $\mathrm{Ti}$-precursor. Both precursors also give $\mathrm{Ti}(\mathrm{C}, \mathrm{N})$ layers, with almost similar results in carbon content for $\mathrm{Ti}(\mathrm{NC} 4 \mathrm{H} 8)_{4}$ as compared with $\mathrm{Ti}\left(\mathrm{NEt}_{2}\right) 4$ and with results in between of $\mathrm{Ti}\left(\mathrm{NEt}_{2}\right)_{4}$ and $\mathrm{Ti}\left(\mathrm{NMe}_{2}\right)_{4}$ for $\mathrm{Ti}(\mathrm{NMeEt})_{4}$, which is not surprising. 


\section{Remote plasmas}

For IC-technology applications, the best results with MO-PECVD of TiN, are obtained using remote plasmas. MO-precursors used in literature are $\mathrm{Ti}\left(\mathrm{NMe}_{2}\right) 4, \mathrm{CpTiC}_{7} \mathrm{H}_{7}$ and $\mathrm{Ti}\left(\mathrm{CBuDAD}_{2}\right)_{2}$, often in combination with $\mathrm{NH}_{3}, \mathrm{H}_{2}$ and $\mathrm{N}_{2}$ as co-reactants $[41,97,100,101,107,113,124,125]$. Ti(NMe 2$) 4$ is almost always used in combination with an ECR plasma [97, 107, 124, 125]. Deposition temperatures range between $100-600^{\circ} \mathrm{C}$. The layer quality seems to be dependent of temperature in combination with deposition rate (see figure 6). At high temperature the film resistivity is independent of deposition rate, where at low temperature only for low deposition rates good quality films are found. This can be explained by the fact that the desorption rate of adsorbed reaction products is reduced at lower temperatures, such that only at low deposition rates, undesired reaction products are not incorporated in the growing layers $[97,107,125]$.

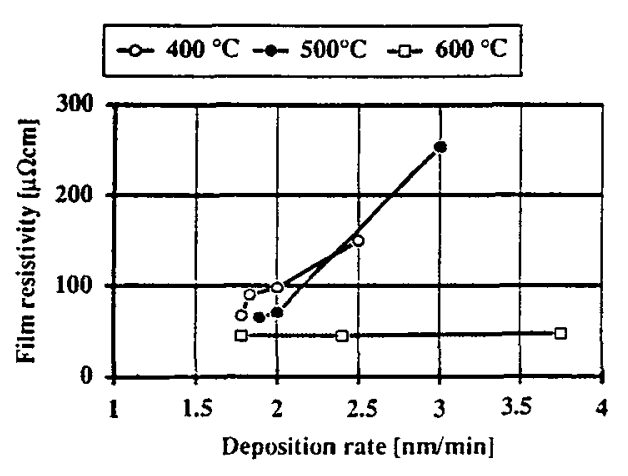

Fig. 6 Influence of the TiN deposition rate on the TiN film resistivity with the ECR-PECVD process using $\mathrm{Ti}\left(\mathrm{NMe}_{2}\right)_{4} / \mathrm{NH}_{3}$ [97].

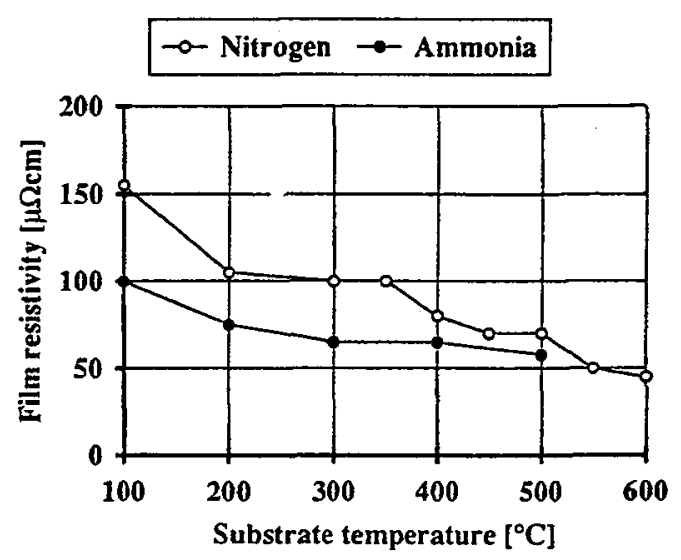

Fig. 7 Film resistivity vs. substrate temperature with the ECR-PECVD process using $\mathrm{Ti}\left(\mathrm{NMe}_{2}\right)_{4}$ in addition with $\mathrm{N}_{2}$ or $\mathrm{NH}_{3}$ [125].

Both nitrogen and ammonia addition resulted in high quality layers with low resistivities $(\geq 45$ $\mu O \mathrm{hm} . \mathrm{cm}$ ), even at $100^{\circ} \mathrm{C}$ (see figure 7) [125]. This is due to low carbon and oxygen amounts (2-5 at\%). The mechanisms that govern the plasma enhanced deposition process are very complex. With the addition of plasma activation the complexity of the chemistry is usually much higher than with thermal CVD [3]. A few initial reports on the possible mechanisms can be found in references [113, 124] Weber et al. [124] have used labelled nitrogen molecules $\left(15_{N}\right)$ and found almost exclusively $\mathrm{Ti}^{15_{\mathrm{N}} \text {. They }}$ suggest that atomic nitrogen and amido radicals generated in the ECR plasma are the active species, and show an initial mechanism by which exclusive formation of $\mathrm{Ti}^{15} \mathrm{~N}$ is explained.

With a remote RF plasma, carbon-free TiN films were deposited using $\mathrm{Ti}\left({ }^{\mathrm{t}} \mathrm{BuDAD}\right) 2$ [41]. The layers were well adherent and scratch resistant, and were almost carbon free. Growth rates were however very low (a few $\mathrm{nm} / \mathrm{min}$ ). Further investigations using this compound would be interesting.

$\mathrm{CpTiC}_{7} \mathrm{H}_{7}$ has also been used [100, 101]. In combination with RF remote plasma activated $\mathrm{N}_{2}$ or $\mathrm{NH}_{3}$. Carbon free films were deposited in the temperature range of $300-600{ }^{\circ} \mathrm{C}$. These layers were gold coloured and consisted of very small randomly oriented, grains $(10 \mathrm{~nm}$ size). Notably they do not exhibit the columnar growth that is typical for thermal CVD TiN layers. Deposition with $\mathrm{N}_{2}$ or $\mathrm{NH}_{3}$ showed only little difference. In both cases, nitrogen rich films were the result. The incorporation of hydrogen in the layer was higher, in the case of $\mathrm{N}_{2}$, which is unexpected. The use of $\mathrm{H}_{2}$ always resulted in small 
amounts of carbon in the layers $[100,101]$. Resistivities of these films were very low and decreased with increasing temperature $(260-100 \mu \mathrm{Ohm} . \mathrm{cm})$.

As can be seen, use of different kinds of glow discharges leads to better layers, whether these are for microelectronic devices or wear resistant purposes.

\section{SUMMARY AND CONCLUSIONS}

Both in IC-technology as in wear resistant applications, a considerable decrease in CVD-TiN deposition temperature has been realised over the years. For both applications, deposition temperatures down to $500^{\circ} \mathrm{C}$ have been proved to be possible. For wear resistant TiN layers, CVD production facilities are operational since a few years [36], while CVD-TiN barrier layers are on the edge of being introduced in ICproduction lines [117, 123].

For IC-technology applications, three TiN CVD process technologies are near to the production stage. $\mathrm{TiCl}_{4} / \mathrm{NH}_{3}$, which offers the best step coverage, while at deposition temperatures above $500^{\circ} \mathrm{C}$ the produced TiN-films do not corrode or degrade overlying aluminium as long as they contain less than 5 at\% chlorine. The two other approaches use chlorine-free $\mathrm{MO}$-precursors namely $\mathrm{Ti}\left(\mathrm{NMe}_{2}\right) 4 / \mathrm{NH}_{3}$ and $\left.\mathrm{Ti}(\mathrm{NEt})_{2}\right) 4 \mathrm{NH}_{3}$, thereby eliminating the afore mentioned chlorine contamination, which remained a con cern for some in the IC-production. As of yet one limitation for the MOCVD process, is the lower step coverage and higher resistivity. Even though the deposition temperature has come down to about $500^{\circ} \mathrm{C}$, it still limits the range of applications within the IC-technology. The usage of alternative MO-precursors has not yet been successful in a substantial lowering of the substrate temperature. The usage of more reactive nitrogen sources, seems to be more promising. The usage of alternative nitrogen precursors, like $t$ butyl amine or methyl hydrazine, has been shown to give good layers at even lower deposition temperatures. The most promising new development seems to be in the usage of atomic nitrogen generated by a remote ECR plasma. Film resistivities lower than $100 \mu \mathrm{Ohm} . \mathrm{cm}$ have been obtained at temperatures as low as $350^{\circ} \mathrm{C}$.

For wear resistant applications only the $\mathrm{TiCl} 4 / \mathrm{N}_{2}$ PECVD process is operational in production [36], using still relatively high deposition temperatures above about $600^{\circ} \mathrm{C}$. Deposition at lower temperatures seems to be possible only with the usage of chlorine free precursors. With almost every presently known chlorine containing precursor, chlorine impurities are found in layers deposited at temperatures below $500^{\circ} \mathrm{C}$, regardless of deposition technique (LPCVD, PECVD). A consequence of the usage of MO-precursors is the incorporation of carbon in the layers. As long as the carbon is bonded as TiC, this itself is not really a disadvantage, as Ti(C,N) layers have a slightly higher hardness. Carbon in the form of organic impurities however tends to degrade the wear resistant layer qualities. Thermal MOCVD, although not yet studied very thoroughly, does not seem to produce good wear resistant TiN layers. PECVD how ever, shows interesting results. Hardnesses up to $2500 \mathrm{HV}$ have already been accomplished. It seems that a large series of MO-precursors are potentially suitable to deposit wear resistant $\mathrm{Ti}(\mathrm{C}, \mathrm{N})$ layers. The ratio of $\mathrm{N} / \mathrm{C}$ in the layers however is very dependent on the applied precursor. Therefore, most probably different MO-precursors will be used, for layers with different qualities and (hard) coating applications.

\section{References}

[1] Wakefield G.F., Yaws C.L. and Bloom J.A., Private communication.

[2] Schintmeister W., Pacher O., Pfaffinger K. and Raine T., J. Electrochem. Soc., 23 (1976) pp. $923-929$. 
[3] Chapman B., 'Glow Discharge Processes', John Wiley \& Sons, (1980).

[4] Ed. Sugano T., 'Applications of Plasma processes to VLSI Technology', John Wiley \& Sons, (1980).

[5] Morancho R., Petit J.A., Dabosi F. and Constant G., J. Electrochem. Soc., 129 (1982) pp. 854-858.

[6] Hänni W. and Hintermann H.E., Proc. of Euro CVD IV, Eindhoven, (1983) pp. 468-472.

[7] Kikuchi N., Oosawa Y. and Nishiyama A, 9th Int. Conf. on CVD, Cincinatti (1984) pp. 728-744.

[8] Gleason E.F. and Hess D.W., Mat. Res. Soc. Symp. Proc. Vol. 68, MRS (1986) pp. 343-349.

[9] Hilton M.R., Narasimhan L.R., Nakamura S., Salmeron M. and Somorjai G.A., Thin Solid Films, 139 (1986) pp. 247260.

[10] Kurtz S.R. and Gordon R.G., Thin Solid Films, 140 (1986) pp. 277-290.

[11] Mayer P. and Stock H.-R., J. Vac. Sci. Technol. A, 4 (1986) pp. 2726-2730.

[12] Reiter N., Berg H. v.d. and König U., VDI Berichte, Nr. 624 (1986) pp. 167-184.

[13] Girolami G.S., Jensen J.A. and Pollina D.M., J. Am. Chem. Soc., 109 (1987) pp. 1579-1580.

[14] Hilton M.R., Vandentop G.J., Salmeron M. and Somorjai G.A., Thin Solid Films, 154 (1987) pp. $377-386$.

[15] Kaloyeros A. and Williams W.S., Appl. Phys. A 42 (1987) pp. 139-143.

[16] Jang D.H., Kim S.B., Chun J.S. and Kim J.G., Plasma Surf. Eng. Vol. 1, 1st Int. Conf. Plasma Surf. Eng., Garmisch Partenkirchen (1988) pp. 147-153.

[17] Lorenz H.P., Plasma Surf. Eng. Vol. 1, 1st Int. Conf. Plasma Surf. Eng., Garmisch Partenkirchen 1988) pp. 139 - 146.

[18] Rie K.-T., Eisenberg S. and Gebauer A., Plasma Surf. Eng. Vol. 1, Ist Int. Conf. plasma Surf. Eng., Garmisch Partenkirchen (1988) pp. 125-133.

[19] Sanders F.H.M., Plasma Surf. Eng. Vol. 1, 1st Int. Conf. Plasma Surf. Eng,, Garmisch Partenkirchen (1988) pp. 163170.

[20] Tabersky R. and Berg H. van den, Plasma Surf. Eng. Vol. 1, 1st Int. Conf. Plasma Surf. Eng., Garmisch Partenkirchen (1988) pp. 133-138.

[21] Wierchon T., Michalski J. and Karpinski T., Plasma Surf. Eng. Vol. 1, Ist Int. Conf. Plasma Surf. Eng., Garmisch Partenkirchen (1988) pp. 177-183.

[22] Brown G.M., Inorg. Chem., 28 (1989) pp. 3028-3032.

[23] Laimer J., Stori H. and Rodhammer P., J. Vac. Sci. Technol. A, 7 (1989) pp. 2952-2959.

[24] Pintchovski F., White T., Travis E., Tobin P.J. and Price J.B., Proc. Tungsten \& Other refractory metals for VLSI Appl. IV, Albuquerque 1988, MRS, (1989) pp. 275-282.

[25] Sherman A., Proc. Tungsten \& Other refractory metals for VLSI Appl. IV, Albuquerque 1988, MRS, (1989) pp. 323329.

[26] Williams L.M., Proc. AESF Ann. Techin. Cont. V, Floth, (1989) pp. 1-13.

[27] Aguero A., Little D. and Lowden P., Mat. Res. Soc. Symp. Proc., 168 (1990) pp. 31 1-316.

[28] Buiting and M.J., Reader A.H., Mat. Res. Soc. Symp. Proc, 168 (1990) pp. 199-204.

[29] Fix R.M., Gordon R.G. and Hoffman D.M., Chem. Mater, 2 (1990) pp. 235-241.

[30] Fix R.M., Gordon R.G. and Hoffman D.M., Mat. Res. Soc. Symp. Proc., 168 (1990) pp. 357-362.

[31] Ishihara K., Yamazaki K., Hamada H., Kamisako K.and Tarui Y., Jpn. J. Appl. Phys., 20 (1990) pp. $2103-2105$.

[32] Lang H. and Seyferth D., Appl. Organometallic Chem., 4 (1990) pp. 599-606.

[33] Ruppert W., Proc. Jpn. Int. Tribology Conf. III, 3 (1990) pp. 1953-1964.

[34] Sherman A., J. Electrochem. Soc., 137 (1990) pp. 1892-1897.

[35] Sherman A., 11 th Int. Conf. on CVD, Seattle (1990) pp. 374-380.

[36] 'Neue Technologie entwickelt', Industrie anzeiger, Sonderdruck Nr. 72/1991 (1991).

[37] Akahori T., Tanihara A. and Tano M., Jpn. J. Appl. Phys., 30 (1991) pp. 3558-3561.

[38] Buiting M.J., Otterloo A.F. and Montree A.H., J. Electrochem. Soc., 138 (1991) pp. 500-505.

[39] Fix R., Gordon R.G. and Hoffman D.M., Chem, Mater., 3 (1991) pp.1138-1148.

[40] Freller H. and Lorenz H.P., Mat. Sci. \& Eng., A 140 (1991) pp. 534-538.

[41] Frenck H.J., Rau C., Bürkner S., Beckmann R., Kulisch W., Kassing R., Trompke C., Rieger J., Schacht U and Dieck H.T., ISPC-10, Bochum (1991).

[42] Ishii Y., Ohtsu H., Adachi T., Ichimura H. and Kobayashi K., Surf. \& Coat. Techn., 49 (1991) pp. $279-283$.

[43] Katz A., Feingold A., Pearton S.J., Nakhara S., Ellington M. and Chakra J., Appl. Phys., 70 (1991) pp. $3666-3677$.

[44] Kim S.B., Choi S.K., Chun S.S. and Kim K.H., J. Vac. Sci. Technol. A, 9 (1991) pp. 2174-2179.

[45] König U., Tabersky R. and Berg H. v.d., Surf. \& Coating Techn., 50 (1991) pp. 57-62.

[46] Meller-Rehbein B., Roesky H.W. and Noltemeyer M., Chem. Ber. 124 (1991) pp. 523-526.

[47] Michalski J. and Wierzchon T., Mat. Sci. \& Eng., A 140 (1991) pp. 499-504.

[48] Musher J.N. and Gordon R.G., J. Electr. Mat., 20 (1991) pp. 1105-1107.

[49] Oguri K., Fujita H. and Arai T., Thin Solid Films, 195 (1991) pp. 77-88. 
[50] Polo M.C., Esteve J. and Morenza J.L., Surf. \& Coatings Techn., 45 (1991) pp. 67-72.

[51] Rie K.-T. and Gebauer A., Mat. Science \& Eng., A 139 (1991) pp. 61-66.

[52] Rie K.-T., Wohle J. and Gebauer A., J. Phys. IV, Coll. C2, Suppl. J. Phys. II, 1 (1991) pp. 397-404.

[53] Sherman A., Jpn. J. Appl. Phys., 30 (1991) pp. 3553-3557.

[54] Stock H.-R., Berndt H. and Mayr P., Surf. \& Coat. Techn., 46 (1991) pp. 15-23.

[55] Tan B.J., Hwan L., Suib S.L. and Galasso F.S., J. Vac. Sci. Technol. A, 9 (1991) pp. 2196-2203.

[56] Taschner C., Leonhardt A., Schonherr M., Wolf E. and Henke J., Mat. Science \& Eng. A, 139 (1991) pp. 67-70.

[57] Ed. Vossen J.L. and Kern W., 'Thin Film Processes II', Academic Press (1991).

[58] Yokoyama N., Hinode K. and Homma Y., J. Electrochem. Soc., 138 (1991) pp. 190-195.

[59] Chatterjee S., Chandrashekhar S. and Sudarshan T.S., J. Mat. Sci., 27 (1992) pp.

[60] Dubois L.H., Zegarski B.R. and Girolami G.S., J. Electrochem. Soc., (1992) pp.

[61] Goto T., Guo C.-Y., Takeya H. and Hirai T., J. Mat. Sci., 27 (1992) pp. 3409-3423.

[62] Gross M.E. and Siegrist T., Inorg. Chem., 31 (1992) pp. 4898-4899.

[63] Hillman J.T., Rice jr. M.J., Srinivas D., Eichman E.C., Triggs W.M., Sommer B., Churley M and Bell C., Conf. Proc. ULSI-IX, MRS, (1992) pp. 311-317.

[64] Hillman J.T., Studiner D.W., Rice Jr. M.J. and Arena C., Microelectr. Eng., 19 (1992) pp. 375-378.

[65] Katz A., Feingold A., Nakhara S., Pearton S.J., Lane E., Geva M., Stevie F.A. and Jones K., J. Appl. Phys., 71 (1992) pp. 993-1000.

[66] Kuypers A.D., Internal ASMI-AMTC activity report, October (1992).

[67] Laurent F., Daures C., Valade L., Choukroun R., Legros J.-P. and Cassoux P., Mat. Res. Soc. Symp. Proc., 271 (1992) pp.875-880.

[68] Laurent F., Zhao J.S., Valade L., Choukroun R. and Cassoux P., J. Anal. \& Appl. Pyr., 24 (1992) pp. 39-49.

[69] Luinstra G.A. and Teuben J.H., Organometallics, 11 (1992) pp. 1793-1801.

[70] Raaijmakers I.J., Vrtis R.N., Sandhu G.S., Yang J., Broadbent E.L., Roberts D.A. and Lagendijk A., Proc. 9th Int. IEEE VLSI Multilevel Interconn. Conf.", Santa Clara, CA,(1992).

[71] Raaijmakers I.J., Vrtis R.N., Yang J., Ramaswami S., Lagendijk A., Roberts D.A. and Broadbent E.K., Mat. res. Soc. Symp. Proc., 260 (1992) pp. 99-105.

[72] Sandhu G.S and Doan T.T., Conf. Proc. ULSI-IX, MRS, (1992) pp. 323-328.

[73] Srinivas D., Hillman J.T., Triggs W.M. and Eichman E.C., Conf. Proc. ULSI-IX, MRS, (1992) pp. 319-322.

[74] Suzuki T., Ohba T., Furumura Y. and Tsuchikawa H., Proc. 9th Int. VLSI Multilevel Interconn. Conf,, Santa Clara, (1992) pp. 979.

[75] Winter C.H., Sheridan P.H., Lewkebandara, T.S. Heeg M.J. and Proscia J.W., J. Am. Chem. Soc., 114 (1992) pp. 10951097.

[76] Berndt H., Stock H.-R. and Mayr H.P., BMFT report, 13N5789, Germany (1993).

[77] Cale T.S., Chaara M.B., Raupp G.B. and Raaijmakers I.J., Thin Solid Films, 236 (1993) pp. $294-300$.

[78] Cale T.S., Raupp G.B., Hillman J.T. and Rice M.J., Conf. Proc. ULSI-VIII, MRS, (1993) pp. 195-202.

[79] Chiu H.-T. and Huang C.C., Mat. Lett., 16 (1993) pp. 194-199.

[80] Hedge R.I., Fiordalice R.W., Travis E.O. and Tobin Ph.J., J. Vac. Sci. Technol. B, 11 (1993) pp. 1287-1296.

[81] Hegde R.I., Fiordalice R.W. and Tobin P.J., Appl. Phys. Lett., 62 (1993) pp. 2326.

[82] Intemann A., Koerner H. and Koch F., J. Electrochem. Soc., 140 (1993) pp. 3215-3222.

[83] Intemann A., VDI-TZ-Proc., 'Dünnschichttechnologien', (1992) pp. 102-107.

[84] Price J.B., Borland J. O. and Selbrede S., Thin Solid Films, 236 (1993) pp. 311-318.

[85] Prybyla J.A., Chiang C.-M. and Dubois L.H., J. Electrochem. Soc., 140 (1993) pp. 2695-2702.

[86] Raaijmakers I.J. and Yang J., Appl. Surf. Sci., 73 (1993) pp. 31-41.

[87] Rie K.-T., Gebauer A. and Woehle J., Surf. \& Coat. Techn., 60 (1993) pp. 385-388.

[88] Rie K.T., Gebauer A. and Woehle J., Plasma Chem. \& Plasma Processing, 13 (1993) pp. 93-101.

[89] Rie K.-T., Gebauer A. and Wöhle J., Mat.-wiss. u. Werkstofftech., 24 (1993) pp. 120-124.

[90] Selbrede S.C., Conf. Proc. ULSI-VIII, MRS, (1993) pp. 259-363.

[91] Spee C.I.M.A., Linden J.L., Van der Zouwen-Assink E.A., Timmer K., Verbeek F., Meinema H.A., Frigo D.M. and Ven S. v.d., J. Phys. IV, Coll. C3, Suppl. J. Phys. II, 3 (1993) pp. 289-296.

[92] Rie K.-T., Wöhle J. and Gebauer A., Surf. \& Coat. Techn., 59 (1993) pp. 202-206.

[93] Sandhu G.S., Meikle S.G. and Doan T.T., Appl. Phys. Lett., 62 (1993) pp. 240-242.

[94] Studiner D.W., Hillman J.T., Arora R. and Foster R.F., Conf. Proc. ULSI-VIII, MRS, (1993) pp. $211-217$.

[95] Täschner C., BMFT report Nr. 13 N 5890, 'Abscheidung neuartiger Hartstoffschichtsysteme durch Zersetzung metallorganischer verbindingen', (1993).

[96] Täschner Ch., Bartsch K. and Leonhardt A., Surface \& Coat. Techn., 59 (1993) pp. $207-211$. 
[97] Weber A., Nikulski R. and Klages C.P., Appl. Phys. Lett., 63 (1993) pp. 325-327.

[98] Arena C., Faguet J., Foster R.F., Hillman J.T. and Srinivas D., Conf. Proc. ULSI-IX, MRS, (1994) pp. $173-180$.

[99] Baumvol I.J.R., Nucl. Instr. \& Methods in Phys. Res. B, 85 (1994) pp. 230-235.

[100] Charatan R.M., Gross M.E. and Eaglesham D.J., Mat. Res. Soc. Symp. Proc., 334 (1994) pp. 329-334.

[101] Charatan R.M., Gross M.E. and Eaglesham D.J., J. Appl. Phys., 76 (1994) pp. 4377-4382.

[102] Chaara M.B., Liao H., Raupp G.B. and Cale T.S., Conf. Proc. ULSI-IX, MRS, (1994) pp. 159-166.

[103] Chen P.J., Truong C.M., Corneille J.S., Oh W.S. and Goodman D.W., Mat. Res. Soc. Symp. Proc., 'Adv. Metall. for devices and Circuits', in press (1994).

[104] Dubois L.H., Polyhedron, 13 (1994) pp.1329-1336.

[105] Eizenberg M., Littau K., Ghanayem S., Mak A., Maeda Y., Chang M. and Sinha A.K., Appl. Phys. Lett., 65 (1994) pp. 2416-2418.

[106] Endler I., Wolf E., Leonhardt A., Beger A. and Richter V., J. Mater. Sci., 29 (1994) pp. 6097-6103.

[107] Gross M.E., Weber A., Nikulski R., Klages C.-P., Charatan R.M., Brown W.L., Dons E. and Eaglesham D.J., Mat. Res. Soc. Symp. Proc., 334 (1994) pp. 323-328.

[108] Rie H. K.-T. and Gebauer A., BMFT report Nr. 13N5793, 'Abscheidung neuer Hartstoff schichtsysteme durch zersetzung metallorganischer verbindungen', (1994).

[109] Harada Y., Akahori T. and Onoda H., Jpn. J. Appl. Phys., 33 (1994) pp. 413-418.

[110] Hillman J.T., Srinivas D., Foster R.F., Graham R.J., Shaapur F. and McCartney M.R., Conf. Proc. ULSI-IX, MRS (1994) pp. 167-172.

[111] Hoffman David M., Polyhedron, 13 (1994) pp. 1169-1179.

[112] In C.B., Kim S.P., Kim Y.I., Kim W.W., Kuk I.H., Chun S.S. and Lee W.J., J. Nuclear Mat., 211 (1994) pp. $223-230$.

[113] Intemann A., Koerner H. and Hieber K., Conf. Proc. ULSI-LX, MRS (1994) pp. 135-142.

[114] Kaizuka T., Shinriki H., Takeyasu N. and Ohta T., Jpn. J. Appl. Phys., 33 (1994) pp. 470-474.

[115] Laurent F., Cyr-Athis O., Legros J.-P., Choukroun R. and Valade L., New J. Chem., 18 (1994) pp. $575-580$.

[116] Lewkebandara T.S., Sheridan Ph.H., Heeg M.J., Rheingold A.L. and Winter C.H., Inorg. Chem., 33 (1994) pp. $5879-$ 5889.

[117] Littau K., Dixit G. and Havemann R.H., Semiconductor Int., July (1994) pp. 183-184.

[118] Ohba T., Itoh K., Furumura Y. and Tsuchikawa H., Conf. Proc. ULSI-IX, MRS (1994) pp. 143-149

[119] Ohto K., Ueno K., Tsunenari K., Numajiri K., Okamura M and Jinba H., Conf. Proc. ULSI-IX, MRS (1994) pp. 151157.

[120] Raaijmakers Ivo J., Thin Solid Films, 247 (1994) pp. 85-93.

[121] Rebenne H. E. and Bhat D. G., Surf. \& Coating Techn., 63 (1994) pp. 1-13.

[122] Sun S.C. and Tsai M.H., Thin Solid Films, 253 (1994) pp. 440-444.

[123] Singer P., Semiconductor Int., August (1994) pp. 57-64.

[124] Weber A., bringmann U., Nikulski R., Pöckelmann R., Klages C.-P., Gross M.E., Brown W.L., Charatan R.M., Dons E. and Eaglesham D.J., Conf. Proc. ULSI-IX, MRS (1994) pp. 125-134.

[125] Weber A., Nikulski R., Klages C.-P., Gross M.E., Brown W.L., Dons E. and Charatan R.M., J. Electrochem. Soc., 141 (1994) pp. 849-853.

[126] Weiller B.H. and Partido B.V., Chem. Mater., 6 (1994) pp. 260-261.

[127] Winter C.H., Lewkebandara S.T., Proscia J.W. and Rheingold A.L., Inorg. Chem., 33 (1994) pp. 1227-1229.

[128] Dixit G.A., Havemann R.H., Halliday L., Strupp J., Velaga A., Roberts B., Jackson R.L. and McInerney E.J., Conf. Proc. ULSI-X, MRS (1995) pp. 321-325.

[129] Dixit G.A., Jain M.K., Chisholm M.F., Weaver T., Havemann R.H., Littau K.A., Eizenberg M., Ghanayem S., Tran H., Maeda Y., Chang M. and Sinha A., Conf. Proc. ULSI-X, MRS (1995) pp. 239-245.

[130] Goldberg C., Eisenbaum E., Komarov S., Faltermeier C., Chen X., Jones M., Ivanova A., Fiordalice R., Pintchovski F., Arkles B., Hepp A. and Kaloyeros A.E., Conf. Proc. ULSI-X, MRS (1995) pp. 247-257.

[131] Intemann A., Koerner H., Ruhl G., Hieber K. and Hartmann E., Conf. Proc. ULSI-X, MRS (1995) pp. $209-221$.

[132] Jackson R.L., McInerney E.J., Roberts B., Strupp J., Velaga A., Patel S. and Halliday L., Conf. Proc. ULSI-X, MRS (1995) pp. 223-229.

[133] Liao H., Hsieh J.J., Toprac A.J., Musher J.N., Gordon R.G., Weiller B.H. and Cale T.S., Conf. Proc. ULSI-X, MRS (1995) pp. 231-237.

[134] McInerney E.J. and Jackson R.L., Conf. Proc. ULSI-X, MRS, (1995) pp. 285-289.

[135] Ohba T., Suzuki T., Yagi H, Furumura Y. and Hatano, J. Electrochem. Soc., 142 (1995) pp. 934-938. 